\title{
KECERNAAN PROTEIN BIJI KAPUK (Ceiba petandra G) SECARA IN VITRO UNTUK PAKAN IKAN
}

\author{
Fitry Primadona ${ }^{1)}$, Supriyono Eko Wardoyo ${ }^{2)^{*}}$, dan O. D. Subhakti Hasan ${ }^{1)}$ \\ ${ }^{1)}$ Sekolah Tinggi Perikanan Cikaret Bogor \\ Jalan Cikaret No.2 Bogor Selatan Bogor, 16001 \\ ${ }^{2)}$ Prodi Biologi FMIPA Universitas Nusa Bangsa Bogor \\ Jl. KH Soleh Iskandar KM 4 Cimanggu Tanah Sareal, Bogor 16166 \\ *email : supriyono.wardoyo@yahoo.com
}

\author{
ABSTRACT \\ Protein Digestibility of Kapok Seeds in Vitro for Fish Feed
}

\begin{abstract}
Kapok seeds is a by-product of agricultural industry having potential to be used as raw material for fish feed as a source of protein and essential fats. The content of the protein in the kapok seed flour is 28 $34 \%$ that is an overwhelming amount to be a great source of protein for fish feed. Feasibility studies are needed, however, the use of kapok seed based on the digestibility of the protein. Pepsin with concentrations of 0.02 ; 0.2 ; and $2 \%$ (in $0.075 \mathrm{~N} \mathrm{HCl}$ solution) kapok seed flour added in three repetitions to test the digestibility of kapok seed invitro. Undigested protein was then analyzed using the kjeldahl method. Determination optimal concentration of pepsin was calculated based on the remaining undigested proteins (pepsin indigest) and compared the amount of protein digestibility of proteins obtained before (pepsin digest). The research results revealed that to digestibility of protein on concentration of 0.02; 0,20 and 2,0\% was 64,43; 68,42; 65,33\%. Statistical test Anova revealed any significant differences of treatment respectively of protein digestibility. Test of Least Square Difference ( $L S D)$ stated that each treatment significantly different. Concentration optimum of enzyme that givethe best digestibility value was $0.20 \%$ digestibility values $68,43 \%$ in the level of error 0.05 .
\end{abstract}

Keywords : Kapok seed flour, protein, pepsin, invitro, optimum digestibility,proximate analysis

\begin{abstract}
ABSTRAK
Biji kapuk merupakan hasil samping industri pertanian yang berpotensi untuk dijadikan bahan baku pakan ikan sebagai sumber protein dan sumber lemak esensial. Komposisi protein pada tepung biji kapuk sebesar 28-34\% adalah jumlah yang sangat potensial untuk dijadikan sumber protein bagi pakan ikan. Akan tetapi diperlukan kajian kelayakan penggunaan biji kapuk berdasarkan kecernaan protein.Pepsin dengan konsentrasi 0,$02 ; 0,2 ;$ dan $2 \%$ (larutan dalam $\mathrm{HCl} 0,075 \mathrm{~N}$ ) ditambahkan pada tepung biji kapuk dengan tiga kali pengulangan untuk menguji kecernaan biji kapuk secara invitro. Protein yang tercerna kemudian dianalisis menggunakan metode kjeldahl. Penentukan konsentrasi pepsin optimal dihitung berdasarkan sisa protein yang tidak tercerna(pepsin indigest) dan dibandingkan jumlah protein awal sehingga didapatkan kecernaan protein (pepsin digest).Hasil penelitian menyatakan kecernaan protein pada konsentrasi 0,$02 ; 0,2 \%$; dan $2 \%$ berturut turut 64,$43 ; 68,42 ; 65,33 \%$. Uji statistik Anova menyatakan setiap perlakuan memberikan perbedaan yang signifikan terhadap kecernaan protein. Uji Least Square Difference (LSD) menyatakan setiap perbandingan perlakuan berbeda. Konsentrasi enzim optimum yang memberikan nilai kecernaan terbaik adalah $0,20 \%(68,43 \%)$ pada tingkat kesalahan 0,05 .
\end{abstract}

Kata kunci: Tepung biji kapuk, protein, pepsin, invitro, kecernaan optimum, proksimat

\section{PENDAHULUAN}

Kebutuhan terhadap protein ingkat seiring dengan peningkatan populasi penduduk dunia. Sejak tahun 1990-an, produksi perikanan tangkap mengalami stagnasi dan cenderung menurun akibat kerusakan lingkungan laut dan upaya penangkapan ikan illegal. Oleh karena itu pemenuhan konsumsi ikan dunia hanya diharapkan dari usaha budidaya ikan. 
Berdasarkan penjelasan di atas, maka perlu dicari bahan baku alternatif terutama yang memanfaatkan bahan pakan lokal. Bahan pakan tersebut harus memenuhi beberapa kriteria diantaranya ketersediaan yang melimpah, harga relatif murah, mudah dicerna oleh ikan, mempunyai kandungan nutrisi yang baik dan tidak berkompetisi dengan manusia (Suprayudi, 2010). Sumber bahan baku pakan yang dapat memenuhi kriteria tersebut diantaranya bahan-bahan hasil samping dari kegiatan agroindustri seperti biji karet, kulit singkong, bungkil kelapa, Palm Kernel Meal (PKM), dan biji kapuk.

Untuk tumbuh dan berkembang ikan membutuhkan nutrien yang cukup dan berimbang. Kebutuhan nutrien tersebut disuplai melalui pakan buatan. Hingga saat ini bahan baku penyusun pakan hampir $85 \%$ diimpor. Hal itu yang menjadi salah satu sebab harga pakan meningkat drastis selama 1 dekade ini. Oleh karena itu perlu dicari alternatif bahan baku dengan persyaratan kualifikasi berbasis lokal, berkualitas, berbasis industri dan harga kompetitif. Biji kapuk merupakan salah satu kandidat yang dipilih karena memenuhi kualifikasi bahan baku pakan ikan(Lampiran 1). Oleh karena itu diharapkan pada penelitian ini bisa mendapatkan hasil kecernaan protein yang optimal dan dijadikan model untuk pengkajian bahan baku lokal lainnya.

Biji kapuk merupakan salah satu kandidat yang dipilih karena memenuhi kualifikasi bahan baku pakan ikan. Selain itu, biji kapuk merupakan bahan baku sebagai sumber protein nabati yang mudah diperoleh, harga murah dan nutrien sesuai kebutuhan ikan, sehingga dapat meningkatkan produksi ikan secara efisien.

Tepung biji kapuk yang berasal dari buah kapuk merupakan hasil ikutan yang penting karena dua pertiga bagian berat buah kapuk adalah biji. Biji kapuk merupakan hasil sampingan pertanian yang cukup banyak di Indonesia terutama di Pulau jawa dan Sulawesi dengan potensi sekitar 114 ribu ton/tahun. Biji kapuk mengandung protein kasar $28-34 \%$, lemak 22-40\% dan bahan ekstrak tanpa nitrogen 25-35\% (Lubis,1998) Minyak biji kapuk mengandung asam oleat sekitar 50\%, asam linoleat $30 \%$, asam palmitat $15 \%$, dan asam lemak linolenat sebesar 5\% (Allen et al.,2002).Berdasarkan karakteristik bahan tersebut maka biji kapuk dapat dijadikan bahan baku pakan sebagai sumber protein dan asam lemak.

Jika makromolekul protein dihidrolisis secara terkendali, maka akan dihasilkan suatu peptida sebagai submakromolekul. Yang kemudian berikutnya akan dihasilkan asam amino sebagai unit molekul. Enzim utama yang digunakan untuk menghidrolisis makromolekul protein adalah pepsin (Hawab, 2004). Pepsin adalah enzim yang berperan dalam pencernaan protein, umumnya memiliki tingkat keaktifan 1:10.000 (AOAC 971,1995)

Informasi kajian ilmiah pemanfaatan biji kapuk pada hewan akuatik masih sangat jarang. Di Belitung, Sumatra Selatan, Suprayudi (2010) melaporkan bahwa ikan bawal tawar (Colossoma macropomum) yang memiliki lambung dapat hidup dan tumbuh dengan diberi pakan $100 \%$ biji kapuk atau kombinasi antara biji kapuk dan pelet masing-masing sebesar 93\% dan $7 \%$, atau $72 \%$ dan $28 \%$. Ikan dengan bobot rata-rata awal $10-12,5$ g menjadi $100-125$ g/ekor setelah dipelihara selama 2 - 3bulan dengan konversi pakan berkisar 2,5-3,5.

Penelitian ini dilakukan untuk mengetahui daya cerna protein biji kapuk yang memiliki kandungan protein yang tinggi dengan pepsin pada lambung ikan(Lampiran 3)yang dilakukan secara invitro. Pepsin merupakan enzim protiolitik, salah satu enzim utama pemecah ikatan polipeptida (protein komplek), yang memecah protein menjadi bentuk yang dapat digunakan oleh ikan(Lampiran 3). Ikatan dari protein kompleks tersebut akan dipecah sebagian menjadi peptida dan sebagian lagi menjadi asam amino(Lampiran 2).Disamping itu mengetahui kandungan 
proksimat (karbohidrat, protein, lemak, serat kasar, air dan abu) dari biji kapuk.

\section{BAHAN DAN METODA}

Penelitian ini dilaksanakan selama 3 bulan dari bulan Oktober - Januaridi Laboratorium Kimia Sekolah Tinggi Perikanan Jalan Cikaret No.2 Po.Box 155, Kelurahan Cikaret, Kecamatan Bogor Selatan, Kota Bogor 16001.

\section{Alat}

Alat-alat yang digunakan adalah alat agitasi/pengocok (dengan kecepatan rendah 15 rotasi permenit, diputar terbalik dan alat dioprasikan dalam inkubator pada suhu $45 \pm 2{ }^{0} \mathrm{C}$ ), timbangan analitik (Mettler Toledo XS205 DU), labu Kjeldahl, , oven merek Binder tipe BD 240, Tanur merek carbolite tipe AAF/ 11/ 3/ PID 301, Blender merek Sharp, corong Buchner, water bath,stevens LRFATexture Analyzer,desicator, incubator, soxhlet, magnetic stirrer, batu didih, pendingin tegak, hot plate, labu penyaring.

\section{Bahan}

Bahan-bahan yang digunakan adalah biji kapuk Ceiba petandra yang berasal dari Bogor,enzim pepsin (porcine gastric mucosa, type $\mathrm{P} 7000$ unit/mg protein, SIGMA) berbentuk tepung yang kemudian dijadikan larutan dengan konsentrasi $\quad 0,02 \%$; $0,2 \%$; $2 \%$ menggunakan $\mathrm{HCL} 0.075 \mathrm{~N}, \mathrm{CaO}$ pro analis dari Merck, $\mathrm{NaOH}$ pro analisa dari Merck, $\mathrm{HCl}$ pro analisa dari Merck, $\mathrm{NaCl}$ pro analisa dari Merck, Polietilen Glikol (PEG) 6000 teknis, asam borak, indikator campuran (brom cresolgreen : metil merah), akuades, larutan Luff, Petroleum Eter pro analisa dari Merck, $\mathrm{BaCl}_{2}$ pro analisa dari Merck, $\mathrm{KCl}$ pro analisa dari Merck, Na-tiosulfat, $\mathrm{KIO}_{3}$, $\mathrm{KI}$ pro analisa dari Merck, $\mathrm{H}_{2} \mathrm{SO}_{4}$ pro analisa dari Merck, $\mathrm{H}_{2} \mathrm{O}_{2}$ pro analisa dari Merck, $\mathrm{BaCl}_{2}$ pro analisa dari Merck, amilum teknis, aseton pro analisa dari Merck, dan Selenium.

\section{Metode Penelitian}

Contoh biji kapuk bebas lemak dicerna secara invitro dengan menggunakan larutan pepsin (hangat) dengan proses agitasi (pengocokan) secara konstan. Residu yang tidak dapat larut diisolasi dengan menggunakan proses penyaringan,pencucian,pengeringan,

kemudian dilakukan analisis kadar protein. Metode yang digunakan untuk protein nabati tapi tidak untuk pakan campuran. Hal ini dikarenakan bahanbahan yang mengandung pakan campuran mengandung karbohidrat kompleks dan campuran lain yang tidak dapat dicerna oleh pepsin. Penelitian dilakukan melalui tahap untuk me-nentukan konsentrasi pepsin optimal dan menentukan tingkat kecernaan biji kapuk menggunakan pepsin secara invitro.

Analisis kadar protein biji kapuk awal dilakukan dengan menggunakan metode mikro Kjeldahl (protein biji kapuk kompleks yang masih mengandung lemak dan kandungan lain). Kemudian dilakukan kadar protein sisa setelah terlebih dahulu sampel diekstraksi hingga diperoleh bebas lemak, ditambahkan dengan larutan pepsin dengan konsentrasi tertentu, lalu diinkubasi selama 16 jam.Selanjutnya hasil inkubasi disaring menggunakan kertas saring dan residu yang tersisa kemudian dianalisis proteinnya sebagai kadar protein sisa (protein akhir). Dari protein awal dan akhir yang diperoleh, dihitung pepsin indigest (jumlah protein yang tidak tercerna) untuk mendapatkan hasil pepsin digest/PD (jumlah protein yang tercerna) yang optimum.

\section{Perbandingan Perlakuan dan Ulangan Biji Kapuk}

Biji kapuk dengan perlakuan yaitu penambahan pepsin dengan konsentrasi tertentu, masing-masing $0 \% ; 0,02 \%$; $0,2 \%, 2 \%$ (pepsin dilarutkan dengan menggunakan larutan $\mathrm{HCl} \quad 0,075 \mathrm{~N})$. Ulangan yang dilakukan pada analisis tersebut adalah sebanyak tiga kali. Konsentrasi penambahan pepsin tersebut 
di atas berdasarkan analisis tingkat kecernaan bahan baku protein nabati. Parameter yang akan diukur adalah tingkat kecernaan protein biji kapuk dengan menggunakan pepsin secara invitro, yang kemudian dianalisis berdasarkan metode AOAC 971,1995.

\section{Ekstraksi Lemak dari Biji Kapuk}

Biji kapuk kering yang diperoleh, dibersihkan dari kapuknya,dan kotoran lainnya, setelah itu dilakukan penghalusan menjadi tepung biji kapuk, setelah itu ditimbang sebanyak 1 gram sampel dimasukkan dalam kertas saring bebas lemak yang telah dibuat selongsong. Selongsong yang berisi sampel dimasukkan ke dalam alat soxhlet dan diberi pelarut petroleum eter sebanyak $150 \mathrm{ml}$ ditampung ke dalam labu penyaring yang telah diberi beberapa batu didih yang telah dikeringkan dan diketahui bobotnya, lalu diekstraksi. Ekstraksi dilakukan selama 4 jam.

Setelah diekstraksi, labu penyaring dikeringkan dalam oven pada $105{ }^{\circ} \mathrm{C}$ selama 1 jam. Kemudian didinginkan dalam eksikator selama 15 menit lalu ditimbang dan dicatat.Kadar lemak kasar dihitung.Sampel yang telah dipakai untuk ekstraksi kemudian dikeringkan untuk menghilangkan sisa pelarut, setelah dikeringkan kemudian ditimbang residu yang bebas lemak, kemudian dilakukan kecernaan protein pepsin $\mathrm{HCl}$ (AOAC 971,1995 ).

\section{Kecernaan Protein Pepsin HCl (AOAC 971, 1995 )}

Contoh tepung biji kapuk yang sudah bebas lemak tersebut kemudian dimasukan kedalam botol dengan tutup berulir. Kemudian kedalam botol yang berisi contoh, dimasukan $150 \mathrm{ml}$ larutan pepsin dengan konsentrasi $0 \% ; 0,02 \%$; $0,2 \% ; 2 \%$ yang telah dihangatkan sebelumnya hingga suhu $42-45^{\circ} \mathrm{C}$, larutan pepsin dituangkan perlahan-lahan dan dipastikan agar seluruh contoh telah dibasahi oleh larutan tersebut. Setelah itu botol ditutup,kemudian diletakan di dalam alat agitator. Lalu botol berisi contoh tersebut dikocok/ diaduk dengan kecepatan 15 rpm secara konstan selama 16 jam pada suhu $45 \pm 2{ }^{0} \mathrm{C}$. Botol kemudian dipindahkan dari alat penyangga dan diletakan pada suatu rak dengan kemiringan 45 derajat, lalu tutup botol tersebut dikendurkan, dan residu dibiarkan mengendap selama 15 menit. Partikel contoh yang menempel pada tutup botol dibilas dengan sedikit air, kemudian larutan dalam botol dituangkan ke saringan secara perlahan-lahan. Setelah seluruh isi dalam botol tersaring, botol tersebut dicuci/dibilas dan kertas saringnya dibilas dengan menggunakan air hangat. Proses pembilasan ini dilakukan berulang hingga residu bebas asam (minimal peng-ulangan pencucian sebanyak 2-3 kali), kemudian dilanjutkan dengan meng-gunakan $15 \mathrm{ml}$ aseton. Kemudian kertas saring berisi residu dikeringkan dalam oven, dan didinginkan. Setelah itu kertas saring yang berisi residu tersebut kemudian dimasukan ke dalam labu kjeldahl, untuk selanjutnya dilakukan penetapan protein yang tidak tercerna oleh pepsin (kadar protein sisa). Penetapan contoh dilakukan dengan kertas saring kosong dengan meng-gunakan kertas saring tanpa residu. Dan hasil yang diperoleh dikurangi dengan hasil dari penetapan contoh masing-masing, untuk mendapatkan kadar protein sisa yang sebenarnya.

\section{Perhitungan dalam Analisis Pepsin}

Perhitungan Kadar Protein Kasar (crude protein )

\section{Kadar protein $=$

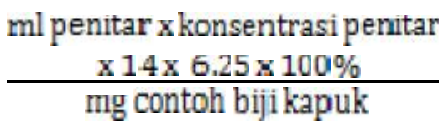

Perhitungan kadar protein sisa ( hasil analisis protein setelah penambahan pepsin ) 


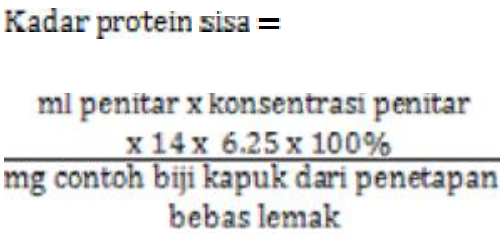

Perhitungan kadar protein yang tidak tercerna oleh pepsin ( pepsin indigest)

Kadar PepsinIndigest $=$

kadar protein sisa $\mathrm{x} 100 \%$

kadar protein kasar

Kadar Protein yang tercerna oleh pepsin ( pepsin digest )

Kecernaan Protein $=100 \%-$ kadar pepsin indigest

\section{Analisis Proksimat}

\section{Penentuan Kadar Air Metoda Gravimetri (AOAC 1995)}

Sampel sebanyak 1 gram dimasukkan ke dalam cawan yang telah diketahui bobotnya, kemudian cawan berisi sampel dimasukkan ke dalam oven pada suhu $105{ }^{\circ} \mathrm{C}$ hingga mencapai bobot yang konstan. Setelah itu cawan diangkat dengan penjepit, dan dimasukkan dalam esikator ditunggu hingga dingin, contoh ditimbang dan bobot yang hilang adalah bobot air.

Perhitungan kadar air (\%)

$=\frac{\text { beratselisihawal }- \text { akhirpengeringa }}{\text { beratawalsampel }} \times 100 \%$

\section{Penentuan Kadar Abu Metoda Gravimetri (AOAC 1995)}

Sampel ditimbang sebanyak 1 gram, dimasukkan dalam cawan yang telah diketahui bobotnya. Lalu dipanaskan dengan pembakar bunsen sampai tidak berasap lagi. Kemudian cawan yang berisi sampel tadi dimasukkan ke dalam tanur dengan suhu $600{ }^{\circ} \mathrm{C}$ selama 5 jam. Setelah itu didinginkan dalam eksikator selama 30 menit, kemudian ditimbang dan dicatat.

Perhitungan kadar abu (\%)

$$
=\frac{\text { berat abu }}{\text { berat awal sampel }} \times 100 \%
$$

\section{Penentuan Kadar Lemak Kasar Metoda Soxhlet (AOAC 1995)}

Sampel ditimbang sebanyak 1 gram, dimasukkan dalam kertas saring bebas lemak yang telah dibuat selongsong. Selongsong yang berisi sampel dimasukkan ke dalam alat soxhlet dan diberi pelarut Petroleum Eter sebanyak $150 \mathrm{ml}$ ditampung ke dalam labu penyaring yang telah diberi beberapa batu didih yang telah dikeringkan dan diketahui bobotnya, lalu diekstraksi. Ekstraksi dilakukan selama 4 jam. Setelah diekstraksi, labu penyaring dikeringkan dalam oven pada $105{ }^{\circ} \mathrm{C}$ selama 1 jam. Kemudian di-dinginkan dalam eksikator selama 15 menit lalu ditimbang dan dicatat.Kadar lemak kasar dihitung.

Perhitungan kadar lemak (\%)

$=\frac{\text { berat setelah pengeringan }}{\text { berat awal sampel }} \times 100 \%$

\section{Penentuan Kadar Protein Kasar Metoda Kyeldhal (AOAC 1995).}

Sampel ditimbang sebanyak 1 gram, dimasukkan ke dalam labu Kjeldahl, ditambahkan 0,65 gram Selenium dan 25 $\mathrm{ml} \mathrm{H}_{2} \mathrm{SO}_{4}$ pekat. Semua bahan dalam labu dipanaskan dalam lemari asam sampai cairan berhenti berasap. Setelah tidak berasap, pemanasan diteruskan dengan api besar sampai mendidih dan larutan menjadi jernih, kemudian didinginkan. Larutan diencerkan dengan menambahkan $10 \mathrm{ml}$ akuades. Larutan dipindahkan ke dalam alat destilasi dan dibilas dua atau tiga kali dengan $3 \mathrm{ml}$ akuades, lalu ditambahkan $10 \mathrm{ml} \mathrm{NaOH}$ 40\%.Uap air dialirkan melewati alat 
destilasi dan destilat ditampung ke dalam erlenmeyer yang berisi $10 \mathrm{ml}$ asam borat dan 2-3 tetes indikator BCG/MM (1:1) atau Mengsel, waktu destilasi ditentukan selama 5 menit (stopwatch). Erlenmeyer yang berisi sulingan dititar dengan $\mathrm{HCl}$ $0,1 \mathrm{~N}$ sampai titik akhir yang ditunjukkan oleh alat makro kjeldahl.

Perhitungan kadar protein $(\%)$

$$
=\frac{(N \times V) H C l \times 14,007 \times 6,25}{\text { berat sampel }(m g)} \times 100 \%
$$

\section{Penentuan Kadar Karbohidrat Metoda Luff and Schoorl (AOAC 1995)}

Sampel ditimbang sebanyak 1 gram, ditambahkan $25 \mathrm{ml} \mathrm{H}_{2} \mathrm{SO}_{4} \quad 1,25 \%$ dan direfluks selama 2 jam. Kemudian didinginkan dan diatur $\mathrm{pH}$ sampai netral dengan larutan $\mathrm{NaOH} 3,25 \%$. Selanjutnya larutan dimasukkan ke dalam labu ukur $100 \mathrm{ml}$ dan ditepatkan dengan akuades. Larutan disaring dengan kertas saring, ditampung dalam gelas piala. Larutan dipipet $10 \mathrm{ml}$ dimasukkan ke dalam erlenmeyer $250 \mathrm{~mL}$. Ditambahkan $25 \mathrm{ml}$ larutan luff dan $15 \mathrm{ml}$ akuades, kemudian direfluks selama 10 menit. Didinginkan, larutan ditambah $10 \mathrm{ml} \mathrm{KI}$ $30 \%$ dan $25 \mathrm{ml} \mathrm{H}_{2} \mathrm{SO}_{4}$ 25\%. Dititrasi dengan $\mathrm{Na}_{2} \mathrm{SO}_{3} \quad 0,1 \quad \mathrm{~N}$ (yang telah distandardisasi). Titrasi dihentikan sampai kuning muda seulas dan ditambahkan indikator pati hingga larutan berwarna biru dan titrasi dilanjutkan hingga larutan berwarna putih susu. Dilakukan penetapan blanko.

Kadar karbohidrat (\%)

$=\frac{\text { Faktor pengenceran } \times m g \text { glukosa } \times 0,90 \times 100 \%}{m g \text { contoh }}$

\section{Penentuan Kadar Serat kasar Metoda Gravimetri (AOAC 1995)}

Prinsip analisis kadar serat kasar adalah menghidrolisis sampel dalam asam kuat encer dan basa kuat encer, sehingga karbohidrat dan protein juga zat - zat lain terhidrolisis dan larut. Serat kasar yang tidak larut dipisahkan dengan penyaringan. Serat kasar yang tertinggal pada kertas serat saring dikeringkan dan ditimbang sampai berat konstan. Ditimbang 1 gram sampel, ditambahkan $50 \mathrm{ml} \mathrm{H}_{2} \mathrm{SO}_{4} 1,25 \%$. Dipanaskan dengan refluks selama 30 menit. Ditambahkan 50 $\mathrm{ml} \mathrm{NaOH} \mathrm{3,25 \%} \mathrm{dan} \mathrm{direfluks} \mathrm{selama} 30$ menit. Disaring, dicuci dengan etanol dan dikeringkan pada suhu $105^{\circ} \mathrm{C}$. Didinginkan dan ditimbang sampai berat konstan.

Perhitungan kadar serat kasar (\%)

$$
=\frac{\text { berat setelah pengeringan }}{\text { berat awal sampel }} \times 100 \%
$$

\section{HASILDAN PEMBAHASAN}

\section{Tingkat Kecernaan Protein}

Kecernaan protein adalah hasil perhitungan dari :

1. Sisa perhitungan yang tidak tercerna oleh pepsin

2. Kadar protein sisa

3. Protein kasar biji kapuk $(28,78 \%)$

Kecernaan protein $0,2 \%$ didapatkan dari $100 \%$ dikurangi sisa protein yang tidak tercerna oleh pepsin. Sisa protein yang tidak tercerna oleh pepsin didapat dari presentasi kadar pepsin sisa dari protein kasar $(28,78 \%)$. Kecernaan protein $=100 \%-31.58 \%=68.43 \%$ Sisa protein yang tidak tercerna oleh pepsin $(31,58 \%)$ didapat dari : $\quad 9,09 \times 100 \%$ $=31.57 \%$, kadar protein sisa $(9,09 \%)$ didapat dari hasil analisis kadar protein $\operatorname{kasar}(28,78 \%)$.

Hasil uji protein sisa pada konsentrasi pepsin $0 \%$ adalah $26,52 \%$ (Gambar.1) masih terjadi proses pencernaan protein oleh pepsin. Hasil ini terjadi karena proses pemutusan ikatan kompleks protein pada biji kapuk melalui proses hidrolisis sehingga terjadi pelepasan protein sederhana yang larut dalam $\mathrm{HCl} 0,075 \mathrm{~N}$. Saat dilakukan penyaringan, protein terlarut ini akan terpisah dari tepung biji kapuk dan 
menyebabkan terjadinya pencernaan protein tanpa adanya enzim pepsin.

Hasil protein yang tidak tercerna terendah (pepsin indigest) pada Gambar 1,yaitu sampel dengan penambahan enzim, terjadi pada perlakukan $0.2 \%$ adalah $31,57 \%$. Hal ini membuktikan kerja enzim hanya terjadi pada konsentrasi optimum, bukan konsentrasi maksimum. Peningkatan konsentrasi enzim secara terus menerus tidak akan menyebabkan peningkatan kecernaan protein oleh enzim. Kecernaan tertinggi diperoleh pada perlakuan konsentrasi enzim $0,2 \%$. Jika dibandingkan dengan literatur (AOAC 971,1995) keadaan yang diperoleh adalah sama yaitu $0,2 \%$.

Pengolahan data secara statistik inferen menggunakan Analysis of Varian, kemudian dilakukan untuk menyatakan secara statistik, apakah hasil yang didapatkan dengan perbedaan perlakuan menunjukkan perbedaan hasil yang nyata yang ditampilkan pada Tabel.1:

Tabel 1. Hasil Uji Anova (Analysis of Varian)

Anova: Single Factor

\begin{tabular}{ccccc} 
SUMMARY & \multicolumn{5}{l}{} \\
\hline Groups & Count & Sum & Average & Variance \\
\hline $0.02 \%$ & 3 & 193.2245 & 64.40815 & 0.000402 \\
$0.20 \%$ & 3 & 205.2814 & 68.42715 & 0.00161 \\
$2,00 \%$ & 3 & 196.0042 & 65.33472 & 0.000402 \\
\hline
\end{tabular}

\begin{tabular}{cccccc} 
ANOVA & \multicolumn{1}{c}{} & & & \\
\hline $\begin{array}{c}\text { Source of } \\
\text { Variation }\end{array}$ & $S S$ & $d f$ & $M S$ & $F$ & $F$ crit \\
\hline Between Groups & 26.57394 & 2 & 13.28697 & 16508.17 & 5.143253 \\
Within Groups & 0.004829 & 6 & 0.000805 & & \\
Total & 26.57877 & 8 & & & \\
\hline
\end{tabular}

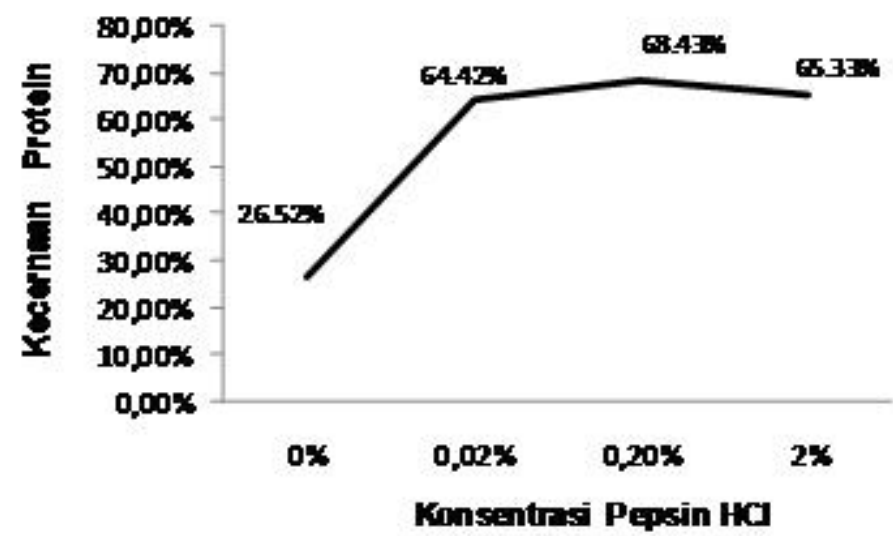

Gambar 1. Grafik Kecernaan Protein ( Digest) 
Tabel 2. Hasil Uji LSD (Least Square Difference)

\begin{tabular}{|c|c|c|c|c|}
\hline & & $\mathrm{D}=0,056$ & 757 & \\
\hline & KS 0,02 & KS 0,20 & KS 2,00 & \\
\hline & 64,42 & 68,38 & 65,32 & \\
\hline & 64,42 & 68,45 & 65,32 & \\
\hline & 64,38 & 68,45 & 65,36 & \\
\hline & 64,41 & 68,43 & 65,33 & \\
\hline Diff 2-1 & & 4,02 & $>$ & 0,13901 \\
\hline Diff 3-2 & & 3,07 & $>$ & 0,13901 \\
\hline Diff 3-1 & & 0,93 & $>$ & 0,13901 \\
\hline
\end{tabular}

Nilai $F$ hitung yang dihasilkan $16.508,17>5,14$. Hipotesis yang menyatakan tidak terdapat perbedaan hasil untuk setiap perlakuan akan ditolak. Dan dinyatakan perlakuan dengan perbedaan konsentrasi enzim memberikan hasil yang berbeda signifikan.

Untuk menyatakan perlakuan mana yang memberikan hasil berbeda, digunakan metode Least Square Difference (LSD), seperti ditampilkan pada tabel 2.

Pengujian menggunakan Least Square Difference (LSD) menunjukan baik semua perlakuan berbeda satu sama lain secara signifikan karena perbedaan hasil untuk masing-masing metode lebih besar dari 0,056757

Keadaan optimum menurut variasi perlakuan konsentrasi enzim disimpulkan terjadi pada konsentrasi penambahan enzim $0,2 \%$. Kecernaan yang diperoleh adalah $68,43 \%$ yang dinyatakan berbeda nyata secara statistik menurut pengujian Anova Single Factor dan Least Square Difference (LSD).

\section{Analisa Proksimat}

Analisis proksimat merupakan kunci untuk menetapkan pemanfaatan bahan tercerna atau energi metabolik makanan, bukan untuk mendefinisikan kandungan zat makanan (Gambar.2). Dari hasil analisis proksimat dapat dipergunakan untuk mengetahui nilai gizi suatu pakan (Suprayudi,2010).
Analisis proksimat pada umumnya dipergunakan untuk mengetahui kandungan air, protein, lemak, karbohidrat, serat kasar dan abu. Menurut Muchtadi (2002), analisis proksimata dalah pengujian laboratorium bahan pakan yang akan diformulasi dan diolah menjadi ransum pelet, crumble, atau mash. Analisis proksimat dilakukan di awal sebelum penelitian, dan parameter yang diananalisis meliputi parameter kadar air, protein, lemak, serat kasar, dan abu.Hasil analisis proksimat bisa dilihat di Tabel 3.

\section{Kadar Air}

Kadar air merupakan karakteristik yang sangat berpengaruh terhadap pakan, terutama terhadap penampakan dan tekstur. Kadar air yang tinggi mengakibatkan bakteri, kapang dan khamir mudah tumbuh, sehingga akan terjadi perubahan. Air sering dikurangi dengan cara penguapan atau pengeringan.

Pada Tabel 3 menunjukkan kadar air yang diperoleh dari biji kapuk jenis C.petandra sekitar $11 \%$ dan $13 \%$, dari hasil penelitian ini kadar air sebanyak $10,72 \%$ menunjukkan umur simpan dan daya tahan tepung biji kapuk. Semakin sedikit kandungan air dalam pakan, kemungkinan rusaknya pakan oleh mikroba semakin kecil. Kandungan air dalam pakan mempengaruhi daya tahan bahan terhadap serangan mikroba. Agar dalam proses penyimpanan bisa ber- 
tahan lama sebaiknya disimpan di tempat yang kering (Watanabe,1998).

\section{Kadar Abu}

Abu merupakan unsur mineral zat anorganik yang tidak mudah menguap dan merupakan sisa yang tertinggal setelah contoh dibakar dan dipijarkan sampai bebas karbon dan air. Kadar abu dalam pakan ditetapkan dengan menimbang sisa mineral sebagai hasil pembakaran bahan organik (Watanabe,1998).

Pada Tabel 3 menunjukkan biji kapuk C.petandrapada hasil penelitian ini didapat kandung abunya sebesar $5,86 \%$, yang tidak jauh berbeda dengan hasil Ariani(1999) sebanyak 6\%.

\section{Kadar Lemak}

Lemak merupakan salah satu makronutrien penting bagi ikan sebagai sumber energi, juga menyediakan asam lemak essensial yang tidak dapat disintesis oleh tubuh ikan. Sebagai sumber energi, lemak mendukung fungsi protein bagi pertumbuhan ikan dan kelangsungan hidup ikan. Sumber steroid untuk menjaga sistem membran, transport lemak, dan sebagai prekusor hormon steroid. Lemak juga membantu dalam penyerapan vitamin yang larut lemak (vitamin A,D,E,K) (Millamena et al.,2002).

Tabel 3. Analisis Proksimat Dibandingkan Terhadap Komposisi Biji Kapuk

\begin{tabular}{lccc}
\hline \multicolumn{1}{r}{ Parameter } & $\begin{array}{c}* \text { Biji kapuk } \\
(\%)\end{array}$ & $\begin{array}{c}* * \text { Biji Kapuk } \\
(\%)\end{array}$ & $\begin{array}{c}\text { Hasil Penel. ini } \\
(\%)\end{array}$ \\
\hline Protein kasar & 25,58 & 29 & 28,79 \\
Lemak & 23,13 & $22-34$ & 20,44 \\
Abu & 6,0 & 6,0 & 5,86 \\
Serat kasar & 18,0 & 20 & 17,66 \\
Karbohidrat & 16,0 & 20 & 16,98 \\
Air & 11,0 & 13,0 & 10,72 \\
\hline
\end{tabular}

*Hasan,2012)

**(Ariani,1999)

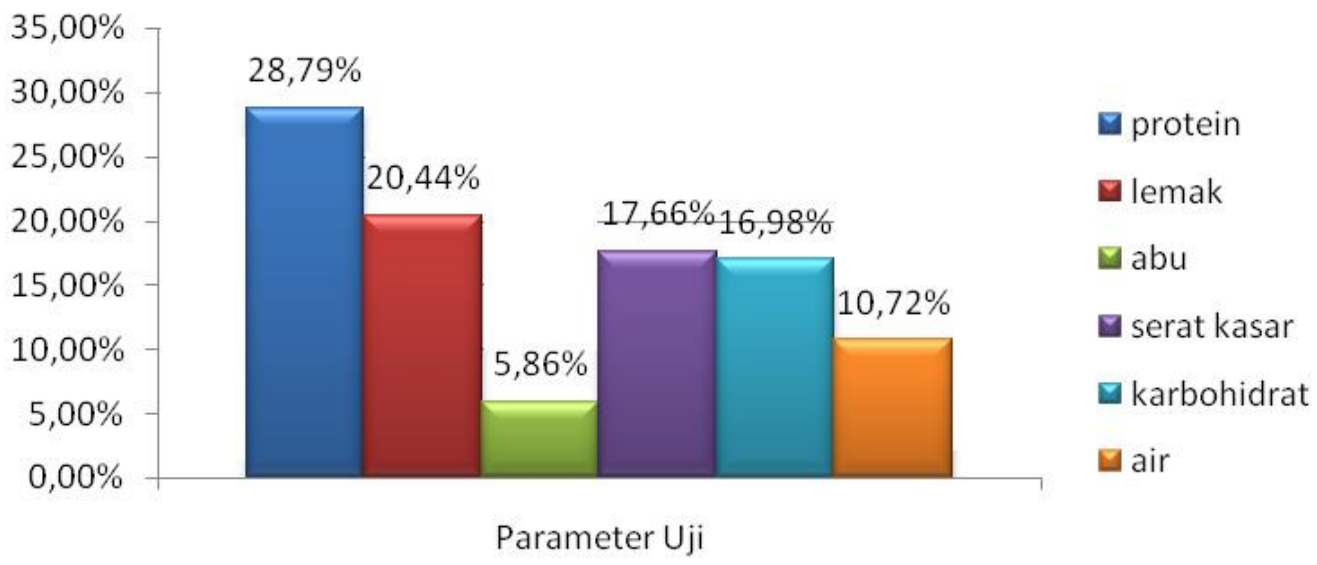

Gambar 2. Grafik Hasil Analisis Kadar Proksimat 
Pada Tabel 3 menunjukkan kadar lemak pada hasil ekstraksi berkisar antara 20,44\%. Jika dibandingkan dengan hasil kadar lemak menurut Hasan (2012) adalah 23,13\%, tidak terlalu jauh bedanya. Kelebihan kandungan lemak pada pakan dapat menyebabkan kerusakan liver yang berakibat penyakit dan kematian, karena ikan mengalami kesulitan dalam mencerna lemak. Kandungan lemak jenuh sangat berbahaya bagi ikan, akan tetapi tetapi kandungan lemak pada biji kapuk memiliki kadar lemak tidak jenuh $71,95 \%$ (Wahyudi, 2005). Hal cukup aman dan diperlukan oleh ikan.

\section{Kadar Protein Kasar}

Protein diperlukan ikan untuk pertumbuhan, memperbaiki dan membangun jaringan tubuh, pembentukan enzim, hormon, dan antibodi dalam tubuh. Protein merupakan suatu molekul kompleks yang terdiri dari asam amino esensial dan nonesensial. Asam amino esensial harus diberikan dari luar tubuh ikan melalui pakan karena tubuh ikan tidak dapat mensintesis sendiri, sedangkan asam amino nonesensial dapat disintesis oleh tubuh ikan. Kandungan kedua asam amino tersebut akan mendukung pertumbuhan ikan secara maksimal (Watanabe,1998).

Jumlah dan kebutuhan protein yang cukup sangat penting dalam pakan ikan budidaya, pada umumnya ikan sangat membutuhkan protein untuk tumbuh dan berkembang. Pada tabel 3 menunjukkan kadar protein pada biji kapuk adalah $28,79 \%$. Jika dibandingkan dengan hasil penelitian Ariani(1999) 29\% protein, hasil penelitian ini tidak berbeda jauh.

Kadar protein bervariasi antara setiap jenis ikan. Tetapi protein adalah komponen penting dalam pakan, dan diperlukan untuk pertumbuhan dan kesehatan ikan. Ikan herbivora butuh protein sekitar $15 \%$ - 25\%dalam kandungan pakan, sedangkan ikan karnivora butuh sedikitnya kandungan 28\% (Muskita, 2012). Kadar protein pada biji kapuk pada penelitian ini sesuai kebutuhan ikan.

\section{Kadar Karbohidrat}

Karbohidrat mempunyai peranan penting dalam menentukan karakteristik bahan pakan, warna dan tekstur. Kebanyakan karbohidrat yang ditemukan di alam terdapat sebagai polisakarida dengan berat molekul yang tinggi (Parakkasi, 1996).

Karbohidrat terbentuk dari komponen yang mengandung unsur $\mathrm{C}, \mathrm{H}$, dan O. Karbohidrat tersediaberlimpahdi alam dan bersumber dari tumbuhan yang biasa menyimpan energinya pada biji, akar, dan umbi (Nabib, 2003). Karbohidrat merupakan sumber energi yang murah dan dapat menggantikan sumber energi yang mahal dari protein. Protein sparring effect dari karbohidrat menjadi sumber energi yang ekonomis, banyak karbohidrat yang dapat dicerna, digunakan dalam formulasi pakan ikan. Sumber karbohidrat seperti pati dapat digunakan sebagai perekat dalam pakan ikan dan udang untuk meningkatkan ketahanan pakan di air (Millamena et al.,2002).

Pada tabel 3 terlihat hasil penetapan uji kadar karbohidrat sekitar 16,98\% kurang lebih sama jika dibandingkan dengan kadar karbohidrat penelitian Hasan (2012) sebesar 16,30\%.

Banyak penelitian melaporkan bahwa pakan yang mengandung karbohidrat tinggi berdampak rendahnya pertumbuhan ikan dan efisiensi pakan ikan. Terdapat kesulitan untuk menentukan tingkat karbohidrat yang optimum bagi ikan karena protein dan lemak mendahului fungsi karbohidrat sebagai sumber energi (Watanabe,1998) dan kegunaan karbohidrat kemungkinan dipengaruhi oleh tingkat protein dan lemak.

Ikan menggunakan karbohidarat sebagai sumber energi. Studi mengenai pemanfaatan karbohidrat pada ikan cukup banyak dilakukan. Informasi yang didapatkan bahwa kemampuan ikan dalam memanfaatkan karbohidrat lebih 
rendah dibandingkan hewan darat, dan setiap jenis ikan berbeda pula dalam kemampuan memanfaatkannya. Karbohidrat merupakan sumber energi yang murah dan berlimpah di alam, sehingga banyak bahan alam untuk dikembangkan sebagai pakan ikan (Ariaty,2003).

Metode yang digunakan pada uji kadar karbohidrat menggunakn metode Luffand Scoorl yaitu merupakan metode yang menghidrolisis karbohidrat menjadi gula pereduksi untuk dapat mereduksi $\mathrm{CuO}$, seperti pada Gambar 3. Kelebihan $\mathrm{CuO}$ akan direduksi dengan KI yang melepaskan $\mathrm{I}_{2}$ yang bebas dalam keadaan asam, kemudian $\mathrm{I}_{2}$ akan dititrasi oleh $\mathrm{Na}_{2} \mathrm{~S}_{2} \mathrm{O}_{3}$.

\section{Kadar Serat Kasar}

Serat pada pakan merupakan bagian dari bahan yang tahan terhadap proses hidrolisis enzim-enzim pencernaan dalam lambung ikan. Serat kasar (crude fiber) yang biasa digunakan dalam analisis proksimat bahan pakan merupakan bagian serat pakan yang tidak dapat dihidrolisis oleh $\mathrm{H}_{2} \mathrm{SO}_{4}$ dan $\mathrm{NaOH}$ pada penentuan serat kasar. Hanya sekitar seperlima sampai setengah dari keseluruhan serat kasar yang benarbenar berfungsi sebagai serat kasar.

Hasil analisis kadar serat kasar pada biji kapuk diperoleh sebesar 17,66\% tidak berbeda dengan kadar serat kasar pada biji kapuk menurut Hasan (2012) $18 \%$. Serat kasar ini merupakan hasil akhir dari proses pencernaan atau pakan yang tidak dapat di cerna oleh ikan. Semakin sedikit persentase serat kasar maka penyerapan akan kandungan gizi pada pakan akan semakin baik (Nabib, 2003).<smiles>[R]C=[C+][GeH2]</smiles>

Gambar 3. Reaksi Antara Aldehid dengan Larutan Luff

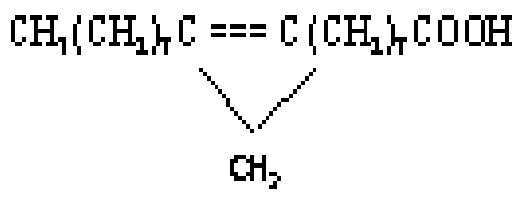

Aean Steinol:

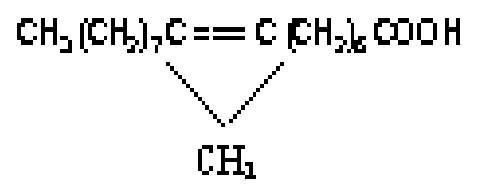

Aeam lublug bt

Gambar 4. Struktur Senyawa Asam Lemak Siklopropenoat (ALS) (Halver \& Hardy, 2002) 


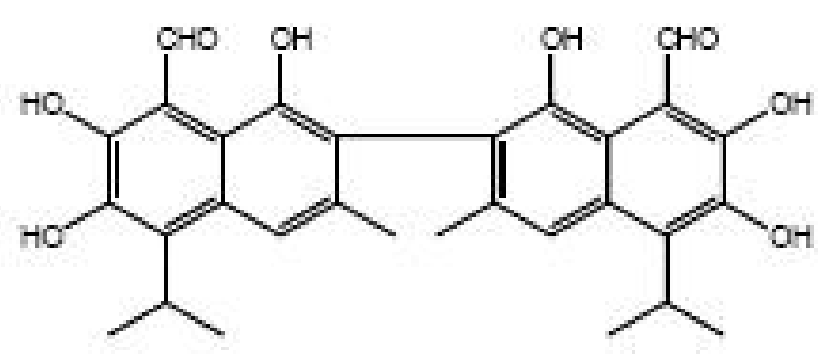

Gambar 5. Struktur Gossypol (Polyphenol) (Cai et al., 2004)

Struktur senyawa siklopropenoat (Halver and Hardy, 2002) dan Struktur gossypol (polyphenol) (Cai et al., 2004)

Biji kapuk mengandung protein kasar 28-34\%, lemak 22-40\% dan bahan ekstrak tanpa nitrogen 25-35\% (Lubis,1998). Namun demikian, biji kapuk juga mengandung zat anti nutrisi yakni gossypol (FG) dan asam lemak siklopropenoat (ALS). FG merupakan nama umum dari polyphenol yang terdapat dalam jaringan tanaman bergenus Gossypium dan beberapa family Malvaceae seperti pada tanaman kapas dan kapuk. Asam-asam Fenolik yang terdapat dalam gossypol dapat membentuk senyawa komplek dengan protein serta menghambat kerja enzim proteolitik seperti tripsin dan pepsin (Morgan, 2000; Cai et al., 2004). ALS pada konsentrtasi yang berlebih dapat menyebabkan nekrosis pada organ dan penurunan pertumbuhan (Muskita, 2012; Li dan Robinson, 2006; Yildirim et al.,2004) Asam lemak siklopropenoat adalah asam lemak tidak jenuh yang mempunyai gugus siklis yaitu gugus siklopropena. Dikenal 2 senyawa dimana tergantung jumlah karbonnya yaitu asam malvalat dan asam sterkulat. asam sterkulat adalah asam 8-(2-oktil 1-siklopropenil) heptanoat(Phelps et al., 1995; Halver \& Hardy, 2002), (Gambar 4 dan Gambar 5).

Asam lemak siklopropenoat dapat dinonaktifkan sehingga dapat mengurangi bahkan menghilangkan sifat toksiknya yaitu dengan hidrogenasi, penambahan dengan polimerasi, halogenasi, substitusi atom hidrogen secara kimia pada cincin siklopropenat. Di samping itu dapat juga dilakukan dengan pemanasan, pengasaman dan sulfitasi yang akan merubah struktur gugus cincin siklopropenat sehingga tidak bersifat racun lagi bagi ternak (Thalib et al., 1998). Zahirma (2012) menyatakan bahwa reaksi oksidasi asam sterkulat dengan kalium permanganat $(\mathrm{KMnO} 4)$ dalam aseton dan hidrogenasi dengan paladium kalsium karbonat (Pd-CaCO3) dalam etanol mempunyai arti penting dalam upaya menekan sifat toksik asam siklopropenoat, karena reaksi ini dapat memecahkan gugus cincin siklo. Sedangkan gossypol merupakan subtansi senyawa phenol berwarna kuning, mempunyai struktur kimia siklik yang berikatan dengan $\mathrm{OH}$,mempunyai rumus molekul $\mathrm{C} 30 \mathrm{H} 30 \mathrm{O} 8$ dengan bobot molekul 518,54 Penelitian Yildirim et al. (2004) menunjukkan bahwa yang mengandung gossypol dengan level lebih dari $800 \mathrm{mg} / \mathrm{kg}$, tidak menunjukkan pengaruh yang berlawanan terhadap bobot dan konsumsi pakan.

\section{KESIMPULAN DAN SARAN}

\section{Kesimpulan}

Berdasarkan hasil penelitian yang diperoleh dapat disimpulkan bahwa :

1. Nilai kecernaan protein biji kapuk secara in vitro pada konsentrasi penambahan enzim 0,$02 ; 0,20$; dan $2,00 \%$ berturut-turut 64,$42 ; 68,42$; dan $65,32 \%$.

2. Kecernaan protein tertinggi pada biji kapuk didapatkan dengan perlakuan penambahan pepsin konsentrasi pepsin $0.2 \%$. 
3. Pada hasil proksimat meliputikadar protein kasar, lemak, abu, serat kasar, karbohidrat, dan kadar air tidak jauh berbeda dengan penelitian sebelumnya.

\section{Saran}

Perlu dilakukan penelitian lebih lanjut mengenai anti nutrisi yang menghambat kecernaan protein pada biji kapuk berupa gossypol dan asam lemak siklopropenoat untuk mendapatkan kecernaan protein yang diperoleh lebih baik (Gambar 4 dan Gambar 5.).

\section{DAFTAR PUSTAKA}

Association of Official Analytical Chemists [AOAC], 1995. Official methods of analysis. 16th edn. AOAC, Arlington. $1094 \mathrm{p}$.

Allen, P.G., L.W. Botsford, A.M. Schuur, and W.E. Johnston, 2002. Bioeconomics of aquaculture. Elsevier, Amsterdam.

Ariani,E., 1999. Uji banding biji kapuk (Ceiba petandra, GAERTN) terhadap dedak, bungkil kelapa dan bungkil kedelai sebagai sumber protein lemak ruminansia. Skripsi.Fakultas Peternakan, Institut Pertanian Bogor.

Ariaty,L.,2003. Morfologi darah ikan mas (Cyprinus carpio), nila merah (Oreochromis sp) dan lele dumbo (Clarias gariepinus) dari Sukabumi. Skripsi. FPIK. IPB. Bogor.

Cai, Y., H. Zhang, Y. Zeng, J. Mo, I. Bao, C. Miao, Bai I, F.Yann, and F.Chen, 2004. An optimazed gossypol highperformance liquid chromatography assay and its application in evaluation of different gland genotypes of cotton. Journal Bio. Sci., 29: 67-71.

Cane,S., 1995. Certificate chemistry 3. England: Chorley \& Pickersgill Ltd. Leeds.

Hawab,M., 2004. Buku ajar biokimia umum. Universitas Nusa Bangsa. Bogor

Halver, J.E., R.W. Hardy,2002. Fish nutrition $\left(3^{\text {rd }} e d\right)$. New York London Academi Press.

Hasan,O.D.S., 2012. Evaluasi biji kapuk (Ceiba petandra Gaertn) berdasar kecernaan, enzimatik, gambaran darah, histologi dan kinerja pertumbuhan sebagai alternatif bahan baku pakan ikan mas (Cyprinus carpio L.). Disertasi. Ilmu Akuakultur. IPB. Bogor.

Lubis, D.A., 1998. Ilmu makanan ternak. P.T. Pembangunan, Jakarta.

Millamena, O.M., R.M. Coloso, and F.P. Pascual, 2002. Nutrition in tropical aquaculture. SEAFDEC,Tigbauanm llo-ilo, Philippines. 221p.

Morgan, S.E., 2000. Gossypol as a toxicant in livestock.pp: 251263. In: G.E. Burrows (eds). The Veterinary clinics of North America : Food Animal Practice. Philadelphia

Muchtadi, D., 2002. Evaluasi nilai gizi pangan. Petunjuk Laboratorium, PAU Pangan dan Gizi. IPB

Muskita, W.H., 2012. Substitusi tepung bungkil kedele, Glycine max., dengan tepung bungkil biji kapuk, Ceiba petandra, dalam 
pakan juvenil udang vaname, Litopenaeus vannamei : Kajian histologi, enzimatik, dan komposisi asam lemak tubuh. Disertasi. Sekolah Pascasarjana Institut Pertanian Bogor. Bogor. 120 hal.

Nabib, R., 2003. Kandungan gizi dan penyakit ikan. Pusat Antar Institut Pertanian Bogor.

Ochse, J.J., M.J. Soule Jr., M.J. Dijkman, C. Wehlberg,1997. Tropical and subtropical agriculture. Vol. II. The McMillan Company, New York.

Parakkasi, A., 1996. Ilmu gizi dan makanan ternak monogastrik. Angkasa. Bandung

Phelps, R.A., F.S.Shenstone, A.R. Kemmerer, R.J. Evans, 1995. A Review of cyclopropenoid compounds: biological effectof some derivatives. Poultry Sci., 44: 358 - 394 .

Rosmawati, 2005. Hidrolisis pakan buatan oleh enzim pepsin dan pankreatin untuk meningkatkan daya cerna dan pertumbuhan benih ikan gurami (Osphronemus gourami Lac.). [Tesis]. Program Pascasarjana. IPB, Bogor.

Setiadi, 2008. Bertanam Kapuk Randu. PT Penerbit Swadaya. Jakarta.

Sihombing, D.T.H., dan S. Simamora, 2009. Penelitian Biji Kapuk untuk Makanan Ternak Babi. Prosiding. Seminar Penunjang Pengembangan Peternakan
Lembaga Penelitian Peternakan. Badan Penelitian dan Pengembangan Pertanian. Departemen Pertanian.

Suprayudi, A., 2010. Pengembangan penggunaan bahan baku lokal biji kapuk untuk pakan ikan : Status Terkini dan Prospeknya. Semiloka Nutrisi dan Teknologi Pakan Ikan. Ispikani. Bogor. 25 hal.

Thalib, A., S. Irawan, S. Dadang, dan S. Ernie, 1998. Perbaikan kualitas bungkil biji kapuk dengan proses sulfitasi. Hasil-hasil Penelitian Tahun Anggaran 1997-1998. Balai Penelitian Ternak, Ciawi. Bogor.

Wahyudi, I., 2005. Tranferifikasi minyak jelantah menjadi bahan bakar alternatif.ITS.Surabaya.

Watanabe, T., 1998. Fish nutrition and mariculturc. Departement of Aquatic Biosciences.Tokyo University of Fisheries.

Yildirim, M., C. Lim, P. Wan, and P.H. Klesius, 2004. Effect of natural free gossypol and gossypolacetic acid on growth performance and resistance of channel catfish (Ictalurus puncatutus) to Edwardsiella ictaluri. Aquaculture Nutrition. $X: 153-165 p p$

Zahirma, U., 2012. Analisa asam siklopropenoat dari bungkil biji kapuk dengan tehnik kromatografi gas. Skripsi. FMIPA, Universitas Indonesia. Jakarta. 43 hal. 
Lampiran 1.Foto Kapuk Ceiba petandra.G (Anonim 2005)

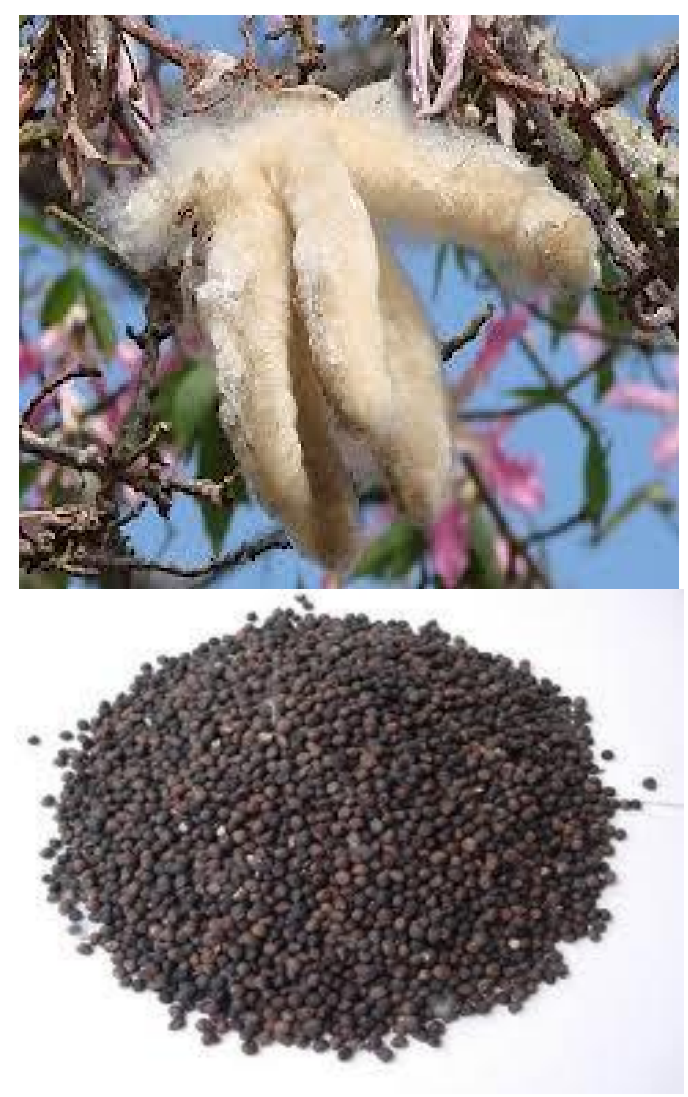

Fotokapuk Ceiba petandra.G (Anonim 2005)

Pohon kapuk (Ceiba petandra Gaertn) termasuk famili Bombaceae mudah tumbuh di daerah tropis dan tumbuh dengan baik pada ketinggian 100-800 $\mathrm{m}$ di atas permukaan laut, tahan terhadap kekurangan air, sehingga dapat ditanam di tegalan, pematang sawah, atau tepi jalan (Setiadi 2008). Klasifikasi Ceiba petandra.G menurut Setiadi. (2008) sebagai berikut :
Kerajaan
: Plantae
Divisi
: Magnoliophyta
Kelas
: Magnoliopsida
Ordo
: Malvales
Famili : Malvaceae (Bombacaceae)
Genus : Ceiba
Spesies : pentandra

Pohon kapuk dapat berproduksi sampai umurnya mencapai 50-60 tahun (Ochse et al. 1997). Setiap pohon kapuk dapat menghasilkan antara 4000-5000 buah per tahun,sehingga pohon kapuk dewasa dapat menghasilkan sekitar 100-200 kg biji kapuk per tahun (Sihombing \&Simamora 2009). Biji kapuk merupakan hasil samping pertanian yang cukup banyak di Indonesia terutama di Pulau Jawa dan Sulawesi dengan potensi sekitar 114 ribu ton/tahun (BPTRO 2006). 
Lampiran 2. Pemecahan Polipeptida Menjadi Asam Amino dengan Penambahan Enzim

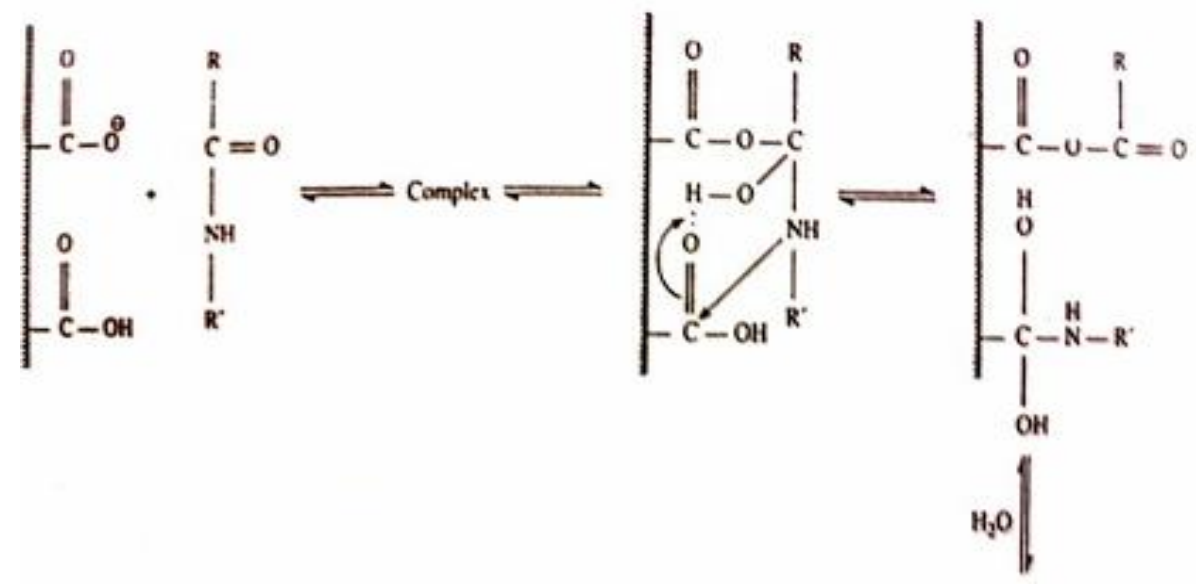

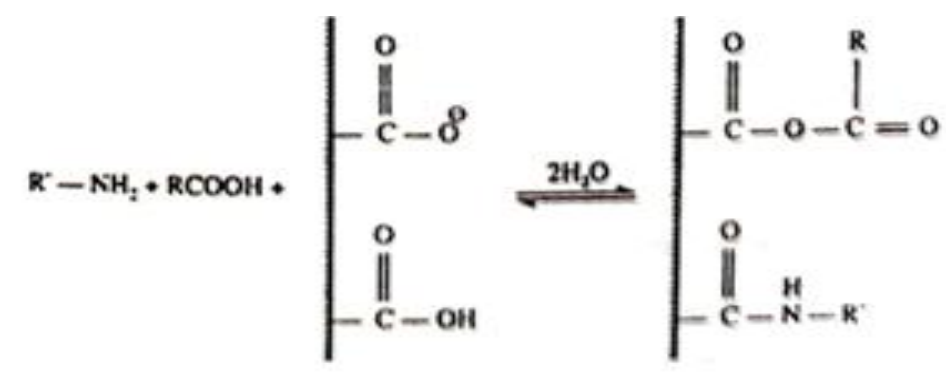

\section{Pemecahan Polipeptida Menjadi Asam Amino dengan Penambahan Enzim}

Kehidupan hewan bersifat "heterotrofik", dimana kebutuhan asam amino untuk sintesis protein tubuhnya harus diperoleh dari makhluk lain. Perpaduan protein nabati dan protein hewani dalam makanan dapat memberikan efek komplementer yang sangat menguntungkan dan menaikkan nilai protein makanan pada tingkat yang terbaik. (Hawab,2004).Hidrolisis protein menggunakan enzim pepsin, yaitu enzim proteolitik yang aktif pada $\mathrm{pH}$ asam. Oleh karena itu, pada lambung ikan pepsin berperan dalampencernaan protein tahap awal yang menghasilkan asam amino dan polipeptida (Cane,1995). Rantai protein dapat terbentuk dengan adanya reaksi antara kepala dari satu molekul asam amino dengan buntut asam amino yang lain dengan melepaskan air<smiles>CNC</smiles>

Ikatan diatas disebut juga dengan ikatan peptide (Cane, 1973). 
Lampiran 3. Sistem Pencernaan ikan dan Pepsin Bentuk Aktif
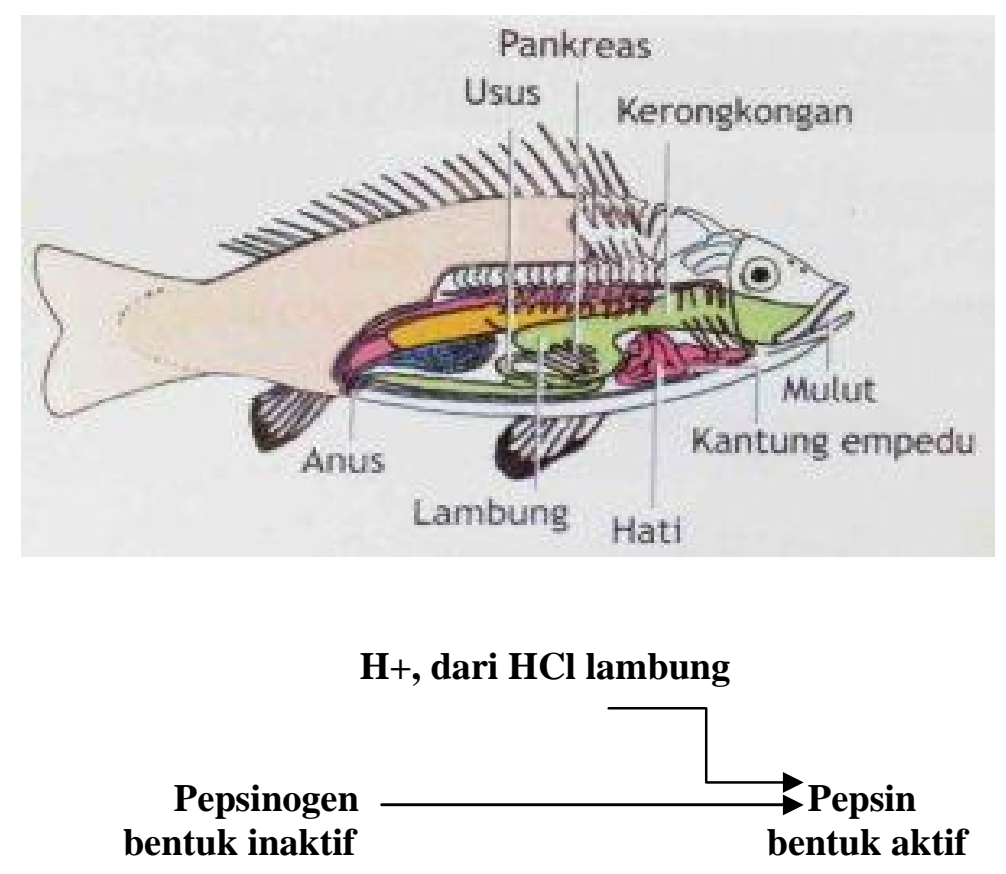

\section{Sistem Pencernaan Ikan dan Pepsin Bentuk Aktif}

Protein makanan dapat digunakan dengan memutuskan ikatan polipeptida dari protein menjadi asam-asam amino. Proses pencernaan ini melibatkan enzim pencernaan sebagai katalisator biologis. Pencernaan pakan adalah penyederhanaan pakan yang awalnya berupa molekul komplek menjadi molekul sederhana. Nutrien yang berbentuk sederhana inilah yang dapat diserap dan diedarkan ke seluruh tubuh. Selama dalam saluran pencernaan, pakan dicerna oleh bermacam-macam enzim menjadi bentuk yang dapat dicerna oleh dinding usus dan masuk ke dalam peredaran darah (Rosmawati, 2005).Lambung berfungsi sebagai penampung makanan dan mencerna makanan (Halver, 2002). Selanjutnya dikatakan bahwa dalam lambung dilengkapi dengan kelenjar lambung yang berfungsi untuk mensekresikan enzim pencernaan.Sel-sel kelenjar eksokrin pada segmen lambung ikan sekaligus mensekresikan pepsin dan asam khlorida $(\mathrm{HCl})$. HCl secara langsung berperan melunakan makanan sehingga menjadi bentuk bubur (hyme) dan menurunkan pH isi lambung yang menyebabkan aktivitas enzim proteolitik terutama pepsin meningkat. 